\title{
Blunted Serotonergic Responsivity in Depressed Inpatients
}

J. John Mann, M.D., P. Anne McBride, M.D., Kevin M. Malone, M.D., Michael DeMeo, M.D., and John Keilp, Ph.D.

We found a $38 \%$ lower maximal prolactin response to an oral challenge dose of $60 \mathrm{mg}$ of dl-fenfluramine relative to placebo in younger ( $<30$ years) depressed inpatients compared with the response in age-matched healthy controls $(\mathrm{p}<.03)$. Severity of depression did not correlate with prolactin response. Prolactin responses in older depressed patients ( $\geqslant 30$ years) did not differ from older controls. Younger depressed patients differed from older depressed patients in terms of earlier age of onset of first lifetime episode of major depression, greater degree of suicidal intent during a recent suicide attempt, double the level of hopelessness on admission to hospital, and a higher rate of comorbid borderline personality disorder. A blunted prolactin response to fenfluramine may be interpreted as evidence for reduced serotonergic function in younger depressed patients and may underlie their observed greater suicidality and hopelessness.

[Neuropsychopharmacology 13:53-64, 1995]
There is evidence that serotonergic function is reduced in patients with major depression (Heninger et al. 1984) and that this effect may be greater in depressed patients with a history of suicide attempts (Mann and Stanley 1986; Mann et al. 1992). Part of this evidence comes from postmortem studies. Reduced levels of serotonin (5-HT) and/or its metabolite 5-hydroxyindoleacetic acid (5-HIAA) have been found in postmortem brainstem specimens from depressed patients and suicide victims (Shaw et al. 1967; Bourne et al. 1968; Pare et al. 1969; Lloyd et al. 1974; Moses and Robins 1975; Beskow et al. 1976; Crow et al. 1984; Korpi et al. 1986). Many but not all studies report reduced density $\left(B_{\max }\right)$ of presynaptic tritiated-imipramine binding sites on serotonergic nerve terminals (Stanley et al. 1982; Paul et al. 1984; Arató et al. 1987; Gross-Isseroff et al. 1989), which in-

From the Department of Neuroscience, New York State Psychiatric Institute (JM, KM, JK), New York, New York, and the Laboratory of Psychopharmacology, Department of Psychiatry (PM, MD), Cornell University Medical College, Ithaca, New York.

Send reprint requests and address correspondence to: J. John Mann, M.D., Department of Neuroscience, New York State Psychiatric Institute, 722 W. 168th Street, Box 28, New York, New York 10032.

Received June 10, 1994; revised January 3, 1995; accepted January 9, 1995. clude the presynaptic 5-HT transporter binding site (Langer et al. 1987), and an increase in the number of postsynaptic 5- $\mathrm{HT}_{2}$ receptors (Stanley and Mann 1983; Crow et al. 1984; Mann et al. 1986; Cheetham et al. 1988; Arango et al. 1990) in the prefrontal cortex of the brain of victims of violent suicide.

Further evidence of an association between reduced serotonergic function and depression comes from studies of depressed patients in vivo. Some but not all studies report that levels of 5-HIAA in the cerebrospinal fluid (CSF) of depressed patients as a group are lower compared with the levels in healthy controls (Åsberg et al. 1976a, b, 1981; Vestergaard et al. 1978; Ågren, 1980a; Gibbons and Davis 1986; Peabody et al. 1987; Nordin 1988; Westenberg and Verhoeven 1988). Most studies also report even lower levels of 5-HIAA in the CSF of those suicide attempters with a depressive disorder as compared with the 5-HIAA levels in depressed nonattempters (Åsberg et al. 1976b; Vestergaard et al. 1978; Ågren 1980b; Asberg and Träskman 1981; Träskman et al. 1981; van Praag 1982; Palaniappan et al. 1983; Roy-Byrne et al. 1983; Lopez-Ibor et al. 1985; Ägren and Niklasson 1986; Edman et al. 1986; Roy et al. 1986; Secunda et al. 1986; Peabody et al. 1987; Nordin 1988; Westenberg and Verhoeven 1988; Jones 
et al. 1990). Several studies have reported a lower number of platelet tritiated-imipramine binding sites (Stanley et al. 1983) and decreased maximal platelet 5-HT uptake (Meltzer et al. 1981; Kaplan and Mann 1982; Carlsson and Carlsson 1988) in depressed patients compared with controls. A limitation of CSF and platelet studies is that they do not adidress the question of whether serotonergic net transmission in the brain is decreased. Actually the most cc nvincing evidence for the role of the serotonergic system in depression is indirect, namely, the antidepressant efficacy of drugs that increase levels of serotonin at postsynaptic receptors by selective inhibition of 5-HT reuptake or by inhibition of catabolism by monoamine oxidase (Peroutka and Snyder 1980; Malone and Mann 1993). It has also been claimed that serotonin precursors are effective in treating depression (van Praag 1982). Depletion of serotonin by parachlorophenylalanine or a tryptophandepleting diet has been reported to reverse the benefit of antidepressant drugs (Shopsin et al. 1975, 1976; Heninger et al. 1992).

Whether net serotonergic transmission is decreased in patients with depression has been assessed by neuroendocrine responses using a variety of direct and indirect serotinin agonists and precursors. The serotonin precursor l-tryptophan has been reported to produce a blunted prolactin response in patients with a major depressive episode (MDE) (Heninger et al. 1984). The most commonly used serotonergic agent in neuroendocrine studies of depression is dl-fenfluramine. An anorectic agent structurally similar to amphetamine, $\mathrm{dl}$ fenfluramine is an indirectly acting central serotonin agonist that causes serotonin release from presynaptic storage granules and inhibits reuptake (McBride et al. 1990). The major metabolite, norfenfluramine, may have a direct effect on postsynaptic receptors (Invernizzi et al. 1992). Acute oral fenfluramine administration increases serum prolactin levels in humans (McBride et al. 1990). This effect appears mediated via hypothalamic afferents from ascending fibers of raphe neurons, which result in release of prolactin from the anterior pituitary gland. Overall, dl-fenfluramine appears relatively selective in assessing the integrity of both the presynaptic and postsynaptic components of this serotonin-mediated response (Meyendorff et al. 1986; Fuller et al. 1988; Mann et al. 1992; Coccaro et al. 1993). Some but not all of these studies employing the fenfluramine challenge have found a blunted prolactin response in depressed patients (see Table 1 for a summary). It is unclear if the lack of agreement in these studies is due to the biochemical heterogeneity of major depression or if there is another explanation. For example, most of these studies did not address whether blunting of the prolactin response correlates with the presence of a major depression or is related to such other manifestations of psychopathology as a history of sui- cidal or aggressive behavior, a comorbid personality disorder, or a subtype of depressive disorder. Moreover, most studies (12 out of 15 ) did not provide data on fenfluramine and norfenfluramine blood levels, so pharmacokinetic and pharmacodynamic effects cannot be differentiated. A placebo control was used in only five of 15 studies, and only three of 15 studies had a placebo control and also assayed drug levels. A related issue is that gender and age have been shown to have significant effects on serotonin function, including the response to fenfluramine (McBride et al. 1990), and most studies have not addressed these effects.

We therefore studied the plasma prolactin response to oral dl-fenfluramine and placebo in order to evaluate the net responsiveness of the central serotonergic system in a group of drug-free hospitalized depressed patients and healthy controls, and to assess the relative contribution of depressive illness, personality disorder, suicidal behavior, sex, and age to central serotonergic responsivity. Blood levels of fenfluramine and its active metabolite norfenfluramine were assayed to assess pharmacokinetic effects.

\section{METHODS}

dl-Fenfluramine, $60 \mathrm{mg}$, or an identical placebo, was administered orally to 26 unipolar depressed inpatients and 26 healthy controls in a single-blind protocol. All subjects were drug-free for a minimum of two weeks before testing. No patient had received fluoxetine or an oral neuroleptic for six weeks prior to study. None of the subjects had taken oral contraceptives for several months. To limit seasonal effects, we studied controls and patients recruited throughout the same time period. The groups (patients and healthy controls) were matched with respect to time of testing and phase of menstrual cycle. All subjects participated after giving written informed consent as required by the Institutional Review Board.

All patients ( 15 females, 11 males) satisfied the Research Diagnostic Criteria for major depressive disorder based on a Schedule for Affective Disorders and Schizophrenia structured clinical interview (Spitzer and Endicott 1978) and were hospitalized on the depression research unit after presenting for evaluation and treatment of depression. The minimum severity criterion was defined as Hamilton Depression Scale (Hamilton 1960) score of greater than 14 on the first 17 items. The Hamilton Depression group mean score was 27. Patients did not have other current comorbid Axis I psychiatric disorders such as anxiety disorders or substance abuse or dependence. All subjects were free of major medical illness based on a medical history screening, a physical examination, and routine laboratory and diagnostic tests. A major medical illness included any 
Table 1. Published Studies Using a Fenfluramine Challenge Test with Depressed Patients

\begin{tabular}{|c|c|c|c|c|c|}
\hline Study & Population & $\begin{array}{c}\text { Fenfluramine } \\
\text { Dose }\end{array}$ & $\begin{array}{l}\text { Drug } \\
\text { Levels }\end{array}$ & Placebo & Finding \\
\hline $\begin{array}{l}\text { Mitchell and Smythe } \\
1990\end{array}$ & 27 MDD, 14 controls & $60 \mathrm{mg}, \mathrm{dl}$ & No & No & PRL $\downarrow$ in mel vs. nonmel \\
\hline Mitchell et al. 1991 & $26 \mathrm{MDD}, 10$ controls & $60 \mathrm{mg}$, dl & No & No & $\begin{array}{l}\text { No difference after controlling } \\
\text { for sex and age }\end{array}$ \\
\hline $\begin{array}{l}\text { O'Keane and Dinan } \\
1991\end{array}$ & $23 \mathrm{MDD}, 16$ controls & $30 \mathrm{mg}, \mathrm{dl}$ & No & No & $\begin{array}{l}\text { PRL vs. controls (no correlation } \\
\text { with severity of depression but } \\
\text { with anxiety) }\end{array}$ \\
\hline Lopez-Ibor et al. 1990 & $\begin{array}{l}17 \text { suicidal patients, } \\
17 \text { controls }\end{array}$ & $\mathrm{dl}$ & No & No & PRL $\downarrow$ and cortisol $\downarrow$ vs. cont \\
\hline Maes et al. 1989 & $\begin{array}{l}40 \text { MDD: compared for } \\
\text { major and minor } \\
\text { depression }\end{array}$ & $60 \mathrm{mg}, \mathrm{dl}$ & No & No & $\begin{array}{l}\text { PRL } \uparrow \text { in major vs. minor } \\
\text { depression }\end{array}$ \\
\hline Targum et al. 1990 & $\begin{array}{l}\text { MDD + panic, } n=12 \\
n=17 \\
\text { MDD-panic, } n=27\end{array}$ & Not available & No & Yes & PD + MDD and PD PRL $\uparrow$ \\
\hline Kasper et al. 1990 & $\begin{array}{l}31 \text { MDD, no normal } \\
\text { controls; effect of } \\
\text { medication }\end{array}$ & $60 \mathrm{mg}$, dl & Yes & Yes & $\begin{array}{l}\text { PRL correl before and after-no } \\
\text { clear treatment effect }\end{array}$ \\
\hline Weizman et al. 1988 & 8 MDD, 8 controls & $60 \mathrm{mg}$, dl & No & No & No difference \\
\hline Lopez-Ibor et al. 1988 & $31 \mathrm{MDD}$ & $60 \mathrm{mg}$, dl & No & No & $\begin{array}{l}\text { No correlation with subtype of } \\
\text { depression or suicidal behavior }\end{array}$ \\
\hline Asnis et al. 1988 & $\begin{array}{l}15 \mathrm{MDD} \text { and } 10 \\
\text { healthy controls }\end{array}$ & $60 \mathrm{mg}, \mathrm{dl}$ & No & No & No difference \\
\hline Siever et al. 1984 & $18 \mathrm{MDD}, 10$ controls & $60 \mathrm{mg}, \mathrm{dl}$ & No & Yes & $\begin{array}{l}\text { Subset of MDD had PRL } \downarrow \\
\text { versus control }\end{array}$ \\
\hline $\begin{array}{l}\text { Mulbauer and Muller- } \\
\text { Oerlinghausen } 1985\end{array}$ & $\begin{array}{l}\text { Bipolar: } 11 \text { on } \mathrm{Li}, 8 \\
\text { untreated euthymic, } \\
11 \text { controls }\end{array}$ & $60 \mathrm{mg}, \mathrm{dl}$ & No & No & $\begin{array}{l}\text { Cortisol responses not altered in } \\
\text { untreated depressed patients }\end{array}$ \\
\hline Coccaro et al. 1989 & $\begin{array}{l}\text { MDD vs. healthy } \\
\text { controls }\end{array}$ & $60 \mathrm{mg}, \mathrm{dl}$ & Yes & Yes & PRL $\downarrow$ in MDD \\
\hline $\begin{array}{l}\text { Lichtenberg et al. } \\
1992\end{array}$ & $\begin{array}{l}24 \mathrm{MDD} \text { and } 21 \\
\text { controls }\end{array}$ & $60 \mathrm{mg}, \mathrm{dl}$ & Yes & Yes & PRL $\downarrow$ in MDD \\
\hline
\end{tabular}

Abbreviations: MDD = major depressive disorder; PRL $=$ prolactin; mel $=$ melancholia; nonmel $=$ nonmelancholia; $\uparrow=$ greater; $\downarrow$ $=$ less or blunted; cont $=$ control; $\mathrm{dep}=$ depression; $\mathrm{PD}=$ personality disorder, $\mathrm{Li}=$ lithium.

neurological disorder, cardiac failure, carcinoma, autoimmune disorder, renal failure, anemia or blood dyscrasias, migraine, carcinoid disease, and obstructive airways disease. Consecutive admissions meeting these criteria were included in this study. Controls were screened by a research psychiatrist to exclude those with a lifetime history of a psychiatric Axis I or Axis II cluster B disorder, or a medical illness. A family history of an Axis I psychiatric disorder in a first-degree relative was also an exclusion criterion. The healthy, drug-free controls (10 females, 16 males) were studied as outpatients.

Further clinical assessment at the time of the fenfluramine challenge testing included the Global Assessment Scale (Endicott et al. 1976) and Beck Hopelessness Scale (Beck et el. 1974). The Suicide Intent Scale (Beck et al. 1974, 1976) was used to characterize suicide attempts made during the current depressive episode. A checklist was used to diagnose cases with comorbid borderline personality disorder or antisocial personality disorder according to the DSM-III-R criteria. Life- time history of aggression was assessed by the BrownGoodwin Scale (Brown et al. 1979, 1982a, b).

Fenfluramine was administered in the second challenge session so as to avoid possible carryover effects on the placebo challenge, and to enhance the effectiveness of the single-blind design during the placebo challenge. Subjects fasted except for water from midnight the night before testing. An intravenous solution of $5 \%$ dextrose in $0.45 \%$ sodium chloride was administered via a forearm vein throughout the challenge period, commencing at approximately 8:00 A.M. and ending at about 2:00 P.M. Approximately $200 \mathrm{ml} /$ hour of intravenous solution was administered over the six-hour span to prevent dehydration and offset the hypoglycemic effect of fenfluramine. Subjects fasted and remained at rest until completion of the challenge test protocol. Blood samples were drawn from a port in the intravenous tubing 15 minutes prior to and immediately before drug or placebo administration, and then hourly for 5 hours. Samples were kept on ice until centrifugation, and plasma samples were stored at $-70^{\circ} \mathrm{C}$. Plasma 
prolactin levels were measured by immunoradiometric assay kits purchased from Hybritech Incorporated (San Diego, CA). The lower limit of sensitivity of the assay was $0.3 \mathrm{ng} / \mathrm{ml}$ of prolactin, and the interassay coefficient of variance was $4 \%$. Plasma fenfluramine and norfenfluramine levels were assayed in samples obtained at 0,3 , and 5 hours using gas-liquid chromatography (Krebs et al. 1984). The minimum detectable levels of fenfluramine and norfenfluramine were $2.0 \mathrm{ng} / \mathrm{ml}$ at $5.0 \mathrm{ng} / \mathrm{ml}$, respectively. The coefficients of variation were $3.4 \%$ for fenfluramine and $6.8 \%$ for norfenfluramine.

The fenfluramine stimulated prolactin response for each subject was calculated by subtracting plasma prolactin concentrations at each time point on the placebo day from the level at the corresponding time point on the fenfluramine day. Peak fenfluraminestimulated prolactin response was determined as the maximum prolactin increase on fenfluramine after subtracting the placebo day prolactin concentration at that same time point. Comparisons between two sets of data were made using $t$-tests; for more than two sets of variables, an analysis of variance for repeated measures was carried out. All significance levels reported are twotailed. Correlations were calculated using the Pearson correlation coefficient method. Data are reported as mean \pm SD, unless indicated otherwise.

\section{RESULTS}

\section{Prolactin Responses to Fenfluramine Relative to Placebo}

In both the 26 controls and the 26 depressed inpatients, fenfluramine elicited a robust increase in plasma prolactin over time compared to placebo $(F=34.4, d f=6,300$, $p<.0001)$. The peak prolactin response occurred between hours 3 and 5 in younger subjects (Figure 1). Older subjects appeared to experience a delay in the peak level to between 4 and 5 hours (Figure 2), although the difference in time to peak level was not statistically significant.

\section{Effect of Sex and Age on Fenfluramine-Induced Prolactin Response in Healthy Controls}

We reported elsewhere, in a study of healthy control subjects that included all of the controls in this study (McBride et al. 1990), that the prolactin response to fenfluramine challenge is significantly greater in females and declines with age. Statistically significant negative correlations were found between age and prolactin increases over placebo levels at 3 hours post drug $(r=$ $-0.45, p<.02), 4$ hours $(r=-0.51, p<.008)$, and peak increase in prolactin $(r=-0.52, p<.007)$ when the entire control group was considered. Examination of the distribution of peak prolactin increase with age in healthy controls suggested lower fenfluramine-stimulated prolactin response in subjects from age 30 onward. When the control group was divided into subjects younger than 30 years of age and those 30 years of age and older, 3-, 4-, and 5-hour and peak prolactin responses no longer correlated significantly with age within either age group. Based on our observation of a marked decline in fenfluramine-induced prolactin response in control subjects around 30 years of age, we compared members of the depressed patient group who were younger than 30 years of age with those aged 30 years and older. The age and gender effects on the prolactin response to fenfluramine were independent of basal prolactin levels.

It has been reported that in women the prolactin response to d-fenfluramine is greater premenstrually (O'Keane et al. 1991), however no significant difference in time since the last menstrual period was reported by patients $(13.4 \pm 11.2$ days for patients receiving fenfluramine) as compared with the controls (19.4 \pm 10.8 days).

\section{Demographic Characteristics and Pharmacokinetic Data in Younger and Older Control and Depressed Groups}

Table 2 lists the characteristics of control and depressed subjects after division by sex and age (younger versus age 30 and older). Within each age group, the mean ages of the control and depressed subjects were well matched. Gender ratios did not differ significantly $(<30$ years: $\chi^{2}=0.10, p<.75 ; \geqslant 30$ years: $\chi^{2}=1.0, p<.31$ ). There were no significant differences in mean 3 - and 5 -hour serum fenfluramine and norfenfluramine levels between the control and depressed subjects in either age group.

\section{Age-Related Differences in Prolactin Response in Control versus Depressed Subjects}

The maximum prolactin response after fenfluramine administration was significantly blunted in the younger depressed patients compared to controls $(14.0 \pm 6.6$ versus $22.7 \pm 9.5 \mathrm{ng} / \mathrm{ml} ; t=2.37, p<.03$ ) (see Figure 1 ). This blunting was statistically significant among younger depressed females compared to control females $(16.7 \pm 6.3$ versus $27.2 \pm 9.9 \mathrm{ng} / \mathrm{ml} ; t=-2.2$, $p<.05)$, and there was a trend toward blunting in younger depressed males versus control males $(8.5 \pm 2.8$ versus $18.3 \pm 7.4 \mathrm{ng} / \mathrm{ml} ; t=-2.15, p<.07)$.

There was a statistically significant difference in the pattern of age effects on prolactin responses in patients compared to controls when the effects of gender were controlled. Controls exhibited a steeper decline after 30 years of age compared to the depressed subjects 


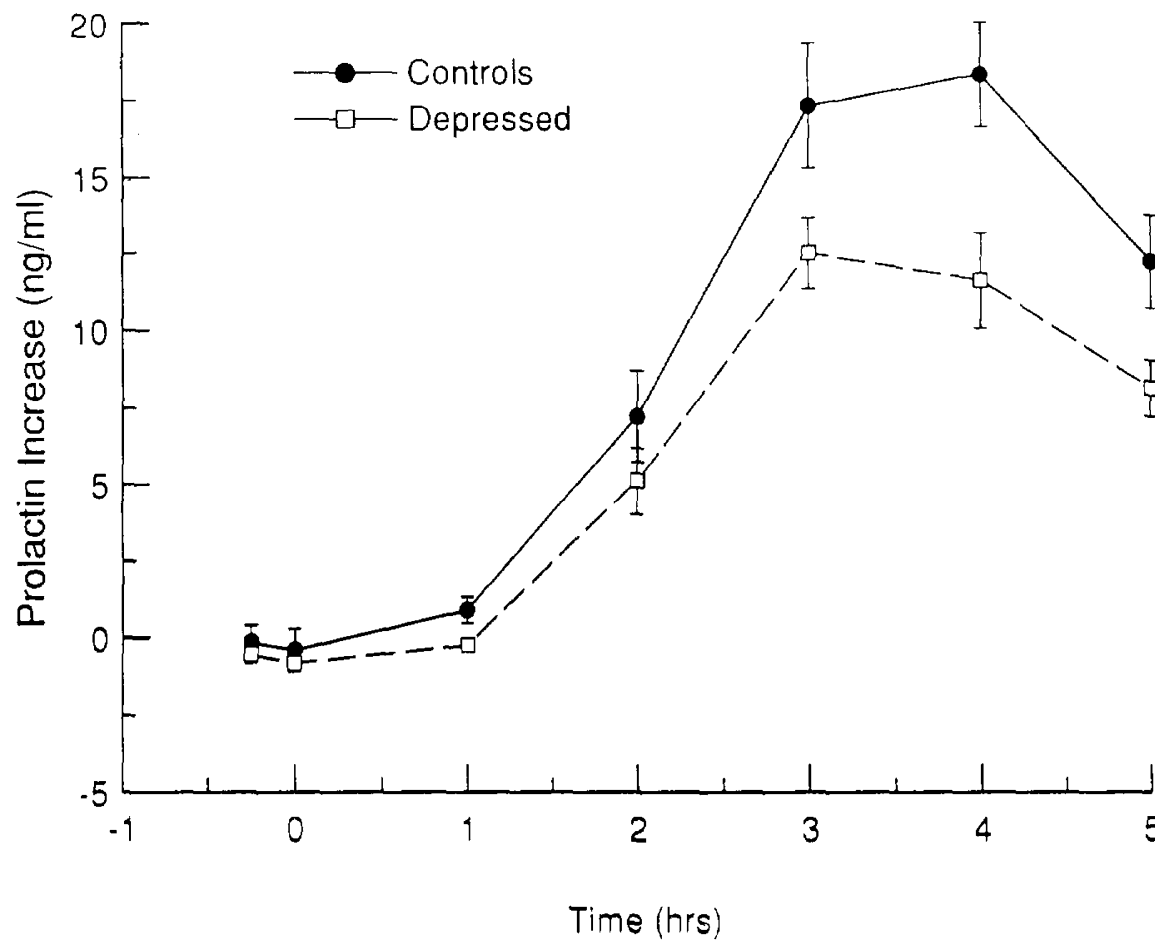

Figure 1. Fenfluramine-induced prolactin response in controls and depressed subjects younger than 30 years of age.

(repeated measures ANOVA $F=8.4, d f=1,48, p<.006$, patient $\times$ age group interaction). This difference remained statistically significant when males were analyzed separately $(F=10.6, d f=1,23, p<.003)$, although the difference among female groups was significant only at a trend level $(F=3.7, d f=1,21, p<.07)$. Controls also exhibited a significantly greater age-related decline in peak prolactin response compared to depressed sub- jects $(F=11.6, d f=1,23, p<.001$, patient $\times$ age group interaction). This interaction was statistically significant for both males $(F=7.5, d f=1,23, p<0.01)$ and females $(F=5.2, d f=1,21, p<.03)$. A three-way ANOVA where age group, diagnostic group, and sex are independent variables and prolactin is the dependent variable proved less informative due to the limited sample size.

Six (four females, two males) of the nine younger

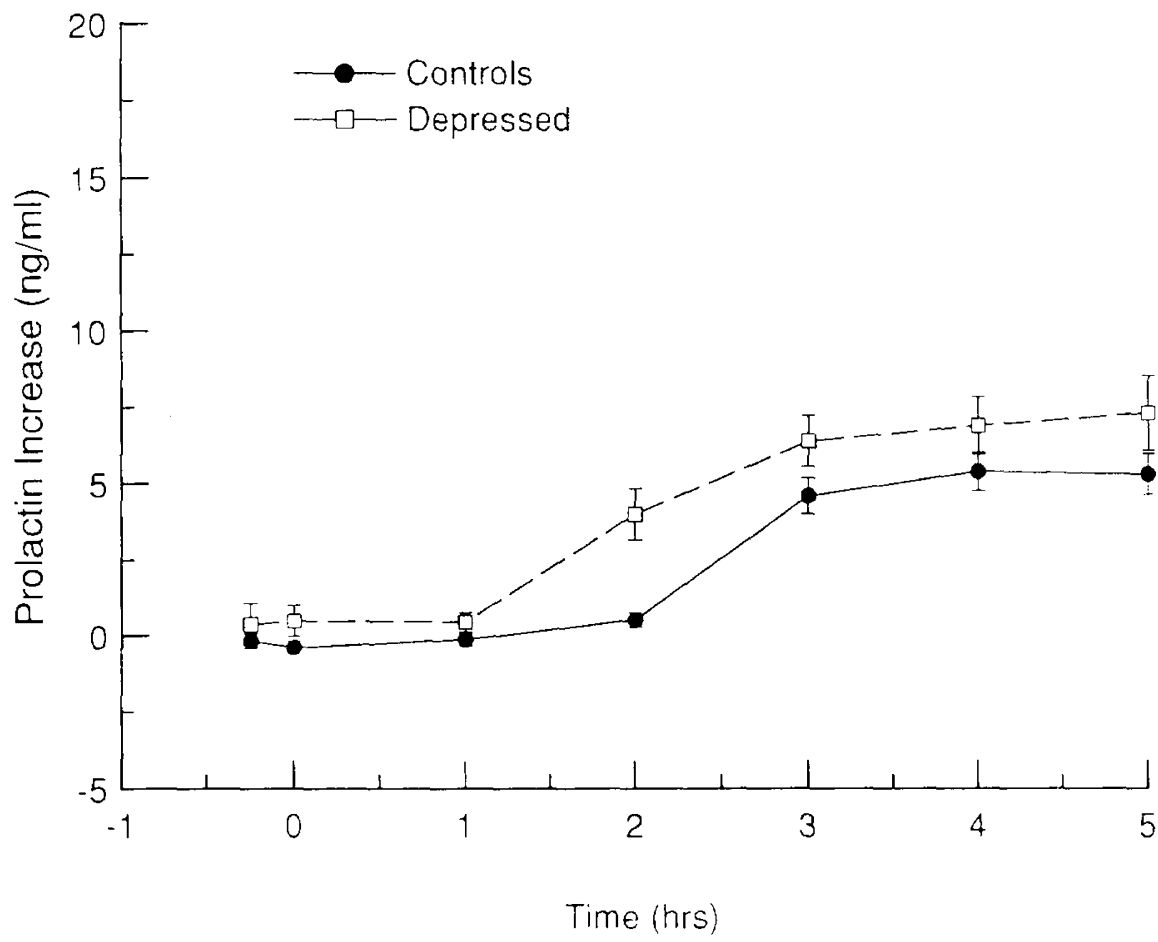

Figure 2. Fenfluramine-induced prolactin response in controls and depressed subjects at or older than 30 years of age. 
Table 2. Demographic Characteristics of and Drug Levels in Younger and Older Control and Depressed Groups

\begin{tabular}{|c|c|c|c|c|}
\hline & \multicolumn{2}{|c|}{$<30$ Years of Age } & \multicolumn{2}{|c|}{$\geqslant 30$ Years of Age } \\
\hline & Controls & Depressed & Controls & Depressed \\
\hline \multicolumn{5}{|l|}{ Demographics } \\
\hline Number of subjects & 12 & 9 & 14 & 17 \\
\hline Male:female ratio & $1: 1$ & $1: 2$ & $5: 2$ & $8: 9$ \\
\hline Age (years) & $24.5 \pm 2.6$ & $24.7 \pm 3.2$ & $46.5 \pm 15.3$ & $46.9 \pm 11.4$ \\
\hline \multicolumn{5}{|c|}{$\begin{array}{l}\text { Fenfluramine }+ \text { norfen } \\
\text { fluramine levels }(\mathrm{ng} / \mathrm{ml}) \text { at } \\
3 \text { hours and } 5 \text { hours }\end{array}$} \\
\hline Male $(3 \mathrm{hr})$ & $57.5 \pm 16$ & $64.0 \pm 9.8$ & $58.4 \pm 14.5$ & $64.0 \pm 17.5$ \\
\hline Female $(3 \mathrm{hr})$ & $67.9 \pm 16.2$ & $85.7 \pm 40$ & $73.5 \pm 10.6$ & $67.8 \pm 10.7$ \\
\hline Male $(5 \mathrm{hr})$ & $60.3 \pm 10.7$ & $51.0 \pm 6.1$ & $55.6 \pm 18.9$ & $58.7 \pm 10.3$ \\
\hline Female $(5 \mathrm{hr})$ & $65.7 \pm 11.9$ & $74.5 \pm 22.1$ & $72.3 \pm 19.3$ & $54.3 \pm 13.8$ \\
\hline
\end{tabular}

depressives had made suicide attempts during the current depressive episode. There were no significant differences between attempters and nonattempters in the peak prolactin response $(13.7 \pm 7.1$ versus $14.3 \pm 6.8$ $\mathrm{ng} / \mathrm{ml} ; t=0.14, p>0.8)$. Among the older subjects, there were no significant differences in prolactin responses between depressed patients and controls at hour $3(6.4 \pm 4.3$ versus $4.6 \pm 3.0 \mathrm{ng} / \mathrm{ml} ; t=1.43, p<.16)$, hour $4(6.9 \pm 4.8$ versus $5.4 \pm 3.2 \mathrm{ng} / \mathrm{ml} ; t=1.07$, $p<.3)$, and hour $5(7.3 \pm 6.2$ versus $5.3 \pm 3.4 \mathrm{ng} / \mathrm{ml}$; $t=1.07, p<.3$ ) (see Fig. 2). The mean maximal prolactin increases in the older depressed patients also did not differ significantly from that in the older controls $(9.4 \pm 6.2$ versus $6.8 \pm 3.5 \mathrm{ng} / \mathrm{ml} ; t=1.37, p<.18)$.

Six (four females, two males) of the 17 older depressed patients had made suicide attempts during their current illness. Three other patients had a past history of suicide attempts but no history of a current attempt. There were no significant differences in the mean peak prolactin increase between current attempters and those who had never made a suicide attempt $(9.7 \pm 6.6 \mathrm{ng} / \mathrm{ml}$ versus $9.4 \pm 6.5 \mathrm{ng} / \mathrm{ml} ; t=0.14, p<.9$ ).

\section{Correlations of Psychopathology with Prolactin Response in Younger and Older Depressed Groups}

Table 3 compares psychopathology at the time of fenfluramine challenge testing in the younger and older depressed groups. Severity of depression as measured by the Hamilton Depression Scale and Global Assessment Scale did not differ between the two groups. The age of onset of the affective disorder was significantly earlier in the younger depressed subjects. However, both groups had suffered a comparable number of episodes of major depression and had been ill for a similar period of time. On admission to hospital, the younger depressives rated themselves as more hopeless than did those in the older group. Also, $78 \%$ (seven) of the nine depressed subjects under age 30 years had a comorbid borderline personality disorder, compared to $29 \%$ (five of 17) of the depressed patients over 30 years of age (Fisher Exact Test, $p=.0375$ ).

Six of the nine depressed subjects under age 30 years and six of 17 older depressives had made a suicide attempt during the current major depressive episode. Suicide attempts in 11 out of 12 were nonviolent (drug or substance overdose, $n=11$ ), and one patient cut his or her wrist. The younger attempters were rated as having greater suicide intent at the time of their attempt compared to the older suicide attempters.

Peak prolactin increase after fenfluramine did not correlate significantly with total Hamilton Depression Scale $(r=0.09, r=0.28)$, Global Assessment Scale $(r=0.004, r=-0.27)$, or the Beck Hopelessness Scale $(r=0.15, r=0.24)$ scores in either the younger or the older age groups of depressed subjects, respectively. Among suicide attempters in both groups, Suicide Intent Scale scores $(r=-0.14, r=-0.23)$ did not correlate significantly with prolactin responses. The correlations remained nonsignificant when age and sex were controlled in a multiple regression analysis.

\section{DISCUSSION}

The significantly blunted peak prolactin response to fenfluramine challenge in depressed patients under age 30 years compared to age-matched controls is consistent with the hypothesis of reduced central serotonergic function in depression.

We found 14 published studies of the effects of fenfluramine challenges on prolactin or cortisol in depressed and personality-disordered patients (see Table 1) (Siever et al. 1984; Muhlbauer and MullerOerlinghausen 1985; Asnis et al. 1988; Lopez-Ibor et 
Table 3. Psychopathology Ratings in Younger and Older Depressed Groups

\begin{tabular}{lccc}
\hline & $<\mathbf{3 0}$ Years of Age & $\geqslant \mathbf{3 0}$ Years of Age & $\boldsymbol{p}$ \\
\hline Hamilton Depression Scale score & $26.5 \pm 8.3$ & $27.8 \pm 6.0$ & $\mathrm{NS}$ \\
Global Assessment Scale score & $43.4 \pm 4.1$ & $44.8 \pm 7.4$ & $\mathrm{NS}$ \\
Age at first episode of depression & $18.0 \pm 4.7$ & $38.8 \pm 15.2$ & .0001 \\
Number of previous major & & & \\
$\quad$ depressive episodes & $3.9 \pm 2.8$ & $4.3 \pm 4.0$ & $\mathrm{NS}$ \\
Beck Hopelessness Scale score & $14.1 \pm 3.4$ & $7.0 \pm 6.4$ & .007 \\
Ratio of attempters to nonattempters & $6 / 9$ & $6 / 17$ & $\mathrm{NS}$ \\
Suicide Intent Scale total score & $20.9 \pm 5.4$ & $12.8 \pm 3.4$ & .01 \\
\hline
\end{tabular}

al. 1988; Weizman et al. 1988; Coccaro et al. 1989; Maes et al. 1989; Kasper et al. 1990; Lopez-Ibor et al. 1990; Mitchell and Smythe 1990; Mitchell et al. 1990; Targum 1990; O'Keane and Dinan 1991; Lichtenberg et al. 1992). The results are not in apparent agreement, perhaps in part because most studies (10 out of 14) lack a placebo control. A placebo challenge can determine whether differential stress responses distinguish the groups, a significant point given that depressed patients may be stress sensitive. The placebo condition can determine if a depression is associated with an abnormal response to the stress of the procedure or if prolactin responses or levels are influenced by the hypothesized reduction in dopaminergic activity, hypothesized to be present in major depression (Kapur and Mann 1992). Another concern is drug levels. Most studies (12 out of 15) did not check blood levels of the drug and therefore were unable to detect potential pharmacokinetic effects. Other potential reasons for apparently divergent results include heterogeneity of patient populations, methodology of the challenge, and effects of residual drugs. A blunted prolactin response was reported by four studies (Siever et al. 1984; Coccaro et al. 1989; Mitchell and Smythe 1990; O'Keane and Dinan 1991). However, one of these studies also reported no difference in prolactin response in patients experiencing nonmelancholic major depression (Mitchell and Smythe 1990). Because most studies did not separately report data on melancholic and nonmelancholic subgroups, we cannot determine the importance of this distinction in explaining differences in reported results. Other studies found no change in patients with major depression versus the controls (Weizman et al. 1988; Targum 1990).

Lopez-Ibor et al. (1990) and Cocarro et al. (1989) found a blunted prolactin response in patients with a personality disorder characterized by suicidal acts but who were experiencing major depression, as compared with the response in patients with a similar disorder but no history of suicide attempts. These results are consistent with our findings in that $78 \%$ of the younger depression cases had comorbid borderline personality disorders, compared to only $29 \%$ of the older group $(p=.0375)$. O'Keane et al. (1992b) found blunted prolactin responses compared to placebo in patients with an- tisocial personality disorder. In contrast, Targum et al. (1990) found increased prolactin responses in patients with major depression and panic attacks or comorbid panic disorder, as compared with responses in patients experiencing major depression without panic attacks and with responses in healthy controls. In a study that raised questions about the diagnostic specificity of these findings, Lerer et al. (1988) reported a blunted prolactin response in schizophrenics compared with the response in controls. Lerer et al. did not provide data on the presence or absence of a history of depression or suicide attempts in their population. Thus, the subtype of depression, the presence of a personality disorder (particularly from cluster B), comorbid panic disorder, or the presence of panic attacks, and a history of suicide attempts, are potential correlates of an altered prolactin response to fenfluramine. A number of other studies have reported altered serotonergically mediated neuroendocrine responses using other agents that also support the indoleamine deficiency hypothesis of depression. Heninger et al. (1984) found a diminished prolactin response to intravenous tryptophan in depressed patients compared to matched controls. This finding has been replicated by others (Koyama et al. 1987; Cowen et al. 1990; Deakin et al. 1990; Price et al. 1991). Domipramine administered intravenously has been found to generate a blunted prolactin response in depressed patients (Anderson et al. 1992; Golden et al. 1992). Increased cortisol responses to 5-hydroxytryptophan in depressed and manic patients have been attributed to increased serotonin receptor sensitivity (Meltzer et al. 1984). Studies of the $5-\mathrm{HT}_{1 \mathrm{~A}}$ receptor have generated conflicting results. Cowen et al. (1994) reported an attenuated hypothermic response in male but not female depressed patients (an effect attributed to the 5-HT $1 \mathrm{~A}$ autoreceptor). Lesch et al. (1991) also found an attenuated hypothermic response in depressed patients to the $5-\mathrm{HT}_{1 \mathrm{~A}}$ agonist ipsapirone. In contrast, growth hormone (Cowen et al. 1994), adrenocorticotropic hormone (Cowen et al. 1994), cortisol (Meltzer and Maes 1994), and prolactin (Meltzer and Maes 1994) responses to buspirone, which are indices of postsynaptic $5-\mathrm{HT}_{1 \mathrm{~A}}$ mediated effects, have been found normal in depressed patients. However, a blunted growth hor- 
mone and adrenocorticotropic hormone response was reported by Lesch (1991) to ipsapirone in depression. Thus, although other general serotonergic neuroendocrine responses appear blunted in depression, it remains to be seen if this effect involves the post-synaptic $5-\mathrm{HT}_{1 \mathrm{~A}}$ receptor. Furthermore, the prolactin response to $\mathrm{m}$-chlorophenylpiperazine ( $\mathrm{mCPP}$ ) in depressed patients is normal (Kahn et al. 1990; Anand et al. 1994). As $\mathrm{mCPP}$ is $5-\mathrm{HT}_{2 \mathrm{C}}$ and $5-\mathrm{HT}_{1 \mathrm{~A}}$ agonist, a mixed agonist/antagonist at the $5-\mathrm{HT}_{2 \mathrm{~A}}$ receptor, and a $5-\mathrm{HT}_{3}$ antagonist, this result also suggests that serotonin receptor responses are not altered.

Fenfluramine-stimulated increase in prolactin levels appears primarily mediated by serotonin rather than other neurotransmitter systems (Fuller et al. 1988). Prolactin responses to the serotonin selective isomer $\mathrm{d}$-fenfluramine correlate closely with responses to dlfenfluramine (Coccaro et al. 1993). We have reported elsewhere that a positive correlation exists between CSF 5-HIAA levels and prolactin responses to fenfluramine in patients (Mann et al. 1992). Norepinephrine appears to play no significant role in prolactin secretion (Fuller et al. 1988). In a number of studies, dopaminergic effects have not been observed in humans after comparable or higher doses of fenfluramine. Meyendorff et al. (1986) gave fenfluramine $(60 \mathrm{mg}$ /day) to suicidal patients for four weeks and found significant reductions in peripheral and central indices of 5-HT function but no changes in CSF homovanillic acid levels. However, differential levels of endogenous dopaminergic activity may potentially modulate prolactin responses to fenfluramine. Because decreased dopaminergic activity has been associated with depression (Kapur and Mann 1992), such a change may be associated with elevated prolactin levels. We found no evidence of elevated prolactin levels during the placebo day in the depressed patients, suggesting that endogenous dopaminergic tonic regulation of prolactin release in depressed patients did not differ from that of the healthy controls.

We found that the blunted prolactin response was evident in younger but not older depressed patients. A diminished prolactin response was not observed in depressed patients age 30 years and older compared with the response of controls in our sample. Older controls had one-third the peak elevation in plasma prolactin after fenfluramine compared with the elevation in controls younger than age 30 years. In contrast, depressed patients did not exhibit an age-related decline in prolactin responses but had a lower response in the younger age range. The age-related decline in fenfluramine-induced responsivity in controls was not due to differences in fenfluramine or norfenfluramine levels between the older and younger groups (see Table 1). Therefore, this finding may reflect age-related differences in the following: uptake of fenfluramine by presynaptic serotonin receptors, stores of presynaptic ser- otonin available for release, or responsivity or number of serotonin postsynaptic receptors mediating prolactin release. It may also reflect an age-related change in dopaminergic control of prolactin release or a direct age effect at the level of the pituitary lactotroph. However, the absence of such effects on placebo-associated prolactin levels suggests our results cannot be attributed to altered dopaminergic function. The significance of the age-related change may be further elucidated by serotonin receptor binding studies in the hypothalamus and direct serotonin and dopamine agonist neuroendocrine challenge studies. The absence of a detectable difference between patients and controls over the age of 30 years may also be due to the reduced range of serotonin responsivity in older subjects, although our data do not even hint at a blunting in older depressed patients.

Previous studies (Table 1) have not evaluated older and younger depressed patients separately or controlled for age of onset of major depressive disorder. Our study results are not due to our subjects' duration of illness or number of episodes, which do not differ in the two groups. But the two groups do differ in terms of age of onset of the first episode of major depression and their levels of hopelessness and suicide intent (both were higher in the younger group). Thus the younger group may have a different form of depressive illness that has biological correlates. Another possible difference between the younger and older depression cases is suggested by the possibility of a higher rate of comorbid borderline personality disorder in the younger cases. Our results are consistent with Cocarro et al. (1989), suggesting that Axis II psychopathology may be more closely related to a blunted prolactin response than major depression.

Most studies have not addressed the question of sex differences in prolactin responses to a serotonergic challenge (see Table 1). It appears that the prolactin response is more robust in females, independent of basal prolactin levels (McBride et al. 1990). Our study and two other studies of depression (O'Keane and Dinan 1991; O'Keane et al. 1992a) also found that female depressed patients have higher prolactin responses to fenfluramine than do depressed males. One study did not find a gender difference (Lichtenberg et al. 1992). Thus overall, most studies find a gender difference that appears present in both patients and controls.

The response of prolactin to tryptophan releasing hormone provides an index of lactotroph function. No difference in prolactin responses to tryptophan releasing hormone have been found in depressed patients (Anderson et al. 1992; Golden et al. 1992; Kjellman et al. 1983), indicating that lactotroph function is not compromised in depression and does not explain the blunted prolactin response to fenfluramine.

We found no differences in the fenfluramine-stim- 
ulated prolactin response between suicide attempters and nonattempters in our depressed patient sample. A correlation between serotonin and suicidal behavior is suggested by findings of reduced postmortem brain levels of 5-HT and 5-HIAA (Shaw et al. 1967; Bourne et al. 1968; Pare et al. 1969; Lloyd et al. 1974; Moses and Robins 1975; Beskow et al. 1976; Crow et al. 1984; Korpi et al. 1986), decreased brain tritiated-imipramine binding sites (Stanley et al. 1982; Paul et al. 1984; Arató et al. 1987; Gross-Isseroff et al. 1989), and increased 5- $\mathrm{HT}_{2}$ brain receptors in suicide victims (Stanley and Mann 1983; Crow et al. 1984; Mann et al. 1986b; Cheetham et al. 1988; Arango et al. 1990), and by lower levels of CSF 5-HIAA (Åsberg et al. 1976a; Ågren 1980a; Träskman et al. 1981; Brunello et al. 1982; van Praag 1982; Banki and Arató 1983; Banki et al. 1984; Lopez-Ibor et al. 1985; Roy et al. 1986) in suicide attempters. Moreover, CSF 5-HIAA appeared reduced in suicide attempters who had made more highly planned suicide attempts in contrast to those whose attempts had been impulsive (Mann et al. 1992). It is conceivable that in this study population, the severity of the suicidal behavior was insufficient to have a detectable relationship to fenfluramine-stimulated prolactin responses. Alternatively, the sample size may have been too small when divided into attempters and nonattempters to detect an effect. However, the younger patients, who had the blunted prolactin response, were also characterized by greater hopelessness, shown by Beck et al. (1985) to correlate with risk for future suicide and suicidal acts. Moreover, the same younger group had higher suicide intent scores. Thus, the blunting of prolactin responses to fenfluramine in younger depressives may be correlated with the predisposition to suicidal behavior and the degree of intent.

Fenfluramine, by inducing presynaptic release of 5-HT and blocking reuptake, increases intrasynaptic levels of 5-HT, which then stimulate postsynaptic receptors (Fuller et al. 1988). Thus it assesses net central serotonergic responsivity. Fenfluramine challenge cannot discriminate between alterations in available presynaptic 5-HT or alterations in postsynaptic 5-HT receptor responsivity. Nor can fenfluramine distinguish effects on specific serotonin receptor subtypes. Future studies are indicated involving neuroendocrine challenges that employ direct 5-HT receptor agonists and give valuable additional information regarding the functional status of the postsynaptic $5-\mathrm{HT}$ receptor subtypes in depressed patients which can extend the findings reported with fenfluramine.

\section{ACKNOWLEDGMENTS}

Dr. Andrew Leon provided statistical assistance. This work was supported by Public Health Service Grant Nos. MH40695 and MH46745. The manuscript was typed by Jean Williams and Irene Diaz. Ann Peters and Ann Gallagher provided valuable technical assistance.

\section{REFERENCES}

Ågren H (1980a): Symptom patterns in unipolar and bipolar depression correlating with monoamine metabolites in the cerebrospinal fluid, I: General patterns. Psychiatry Res 3:211-223

Ågren H (1980b): Symptom patterns in unipolar and bipolar depression correlating with monoamine metabolites in the cerebrospinal fluid, II: Suicide. Psychiatry Res 3: 225-236

Ågren H, Niklasson F (1986): Suicidal potential in depression: Focus on CSF monoamine and purine metabolites. Psychopharmacol Bull 22(3):656-660

Anand A, Charney DS, Delgado PL, McDougle CJ, Heninger GR, Price LH (1994): Neuroendocrine and behavioral responses to intravenous $m$-chlorophenylpiperazine (mCPP) in depressed patients and healthy comparison subjects. Am J Psychiatry 151:1626-1630

Anderson IM, Ware CJ, Da Roza Davis JM, Cowen PJ (1992): Decreased 5-HT-mediated prolactin release in major depression. Br J Psychiatry 160:372-378

Arango V, Ernsberger P, Marzuk PM, Chen J-S, Tierney H, Stanley M, Reis DJ, Mann JJ (1990): Autoradiographic demonstration of increased serotonin $5-\mathrm{HT}_{2}$ and $\beta$-adrenergic receptor binding sites in the brain of suicide victims. Arch Gen Psychiatry 47:1038-1047

Arató M, Tekes K, Palkovits M, Demeter E, Falus A (1987): Serotonergic split brain and suicide. Psychiatry Res 21: 355-356

Åsberg M, Träskman L (1981): Studies of CSF-5-HIAA in depression and suicidal behavior. Adv Exp Med Biol 133:739-752

Åsberg M, Thorén P, Träskman L, Bertilsson L, Ringberger V (1976a): Serotonin depression - A biochemical subgroup within the affective disorders? Science 191:478-480

Åsberg M, Träskman L, Thorén P (1976b): 5-HIAA in the cerebrospinal fluid: A biochemical suicide predictor? Arch Gen Psychiatry 33:1193-1197

Åsberg M, Bertilsson L, Rydin E, Schalling D, Thorén P, Träskman-Bendz L (1981): Monoamine metabolites in cerebrospinal fluid in relation to depressive illness, suicidal behavior and personality. Bioscience 31:257-271

Asnis GM, Eisenberg J, van Praag HM, Lemus CZ, Harkavy Friedman JM, Miller AH (1988): The neurodocrine response to fenfluramine in depressives and normal controls. Biol Psychiatry 24:117-120

Banki CM, Arató M (1983): Amine metabolites and neuroendocrine responses related to depression and suicide. J Affective Disord 5:223-232

Banki CM, Arató M, Papp Z, Kurcz M (1984): Biochemical markers in suicidal patients: Investigations with cerebrospinal fluid amine metabolites and neuroendocrine tests. J Affective Disord 6:341-350

Banki CM, Arató M, Kilts CD (1986): Aminergic studies and cerebrospinal fluid cations in suicide. Ann N Y Acad Sci 487:221-230 
Beck AT, Weissman A, Lester D, Trexler L (1974): The measurement of pessimism: The hopelessness scale. J Consult Clin Psychol 42(6):861-865

Beck AT, Weissman A, Lester D, Trexler L (1976): Classification of suicidal behavior, II: Dimensions of suicidal intent. Arch Gen Psychiatry 33:835-837

Beck AT, Steer RA, Kovacs M, Garrison B (1985): Hopelessness and eventual suicide: A 10-year prospective study of patients hospitalized with suicidal ideation. Am J Psychiatry 142(5):559-563

Beck RW, Morris JB, Beck AT (1974): Cross-validation of the suicidal intent scale. Psychol Rep 34:445-446

Beskow J, Gottfries CG, Roos BE, Winblad B (1976): Determination of monoamine and monoamine metabolites in the human brain: Post mortem studies in a group of suicides and in a control group. Acta Psychiatr Scand 53:7-20

Bourne HR, Bunney WEJ, Colburn RW, Davis JM, Shaw DM, Coppen AJ (1968): Noradrenaline, 5-hydroxytryptamine, and 5-hydroxyindoleacetic acid in hindbrains of suicidal patients. Lancet 2:805-808

Brown GL, Goodwin RK, Ballenger JC, Goyer PF, Major LF (1979): Aggression in human correlates with cerebrospinal fluid amine metabolites. Psychiatry Res 1:131-139

Brown GL, Ebert MH, Goyer PF, Jimerson DC, Klein WJ, Bunney WEJ, Goodwin FK (1982a): Aggression, suicide and serotonin: Relationships to CSF amine metabolites. Am J Psychiatry 139:741-746

Brown GL, Goodwin FK, Bunney WEJ (1982b) Human aggression and suicide: Their relationship to neuropsychiatric diagnoses and serotonin metabolism. Adv Biochem Psychopharmacol 34:287-307

Brunello N, Chuang DM, Costa E (1982): Different synaptic location of mianserin and imipramine binding sites. Science 215:1112-1115

Carlsson M, Carlsson A (1988): A regional study of sex differences in rat brain serotonin. Prog Neuro-Psychopharmacol \& Biol Psychiatry 12:53-61

Cheetham SC, Crompton MR, Katona CLE, Horton RW (1988): Brain 5- $\mathrm{HT}_{2}$ receptor binding sites in depressed suicide victims. Brain Res 443:272-280

Coccaro EF, Siever LJ, Klar HM, Maurer G, Cochrane K, Cooper TB, Mohs RC, Davis KL (1989): Serotonergic studies in patients with affective and personality disorders. Arch Gen Psychiatry 46:587-599

Coccaro EF, Kavoussi RJ, Hauger R (1993): PRL responses to d-fenfluramine and D, L-fenfluramine in man. In Proc ACNP 32d Annual Meeting, (abstract 160)

Cowen PJ, McCance SL, Gelder MG, Grahame-Smith DG (1990): Effect of amitriptyline on endocrine responses to intravenous L-tryptophan. Psychiatry Res 31:201-208

Cowen PJ, Power AC, Ware CJ, Anderson IM (1994): 5- $\mathrm{HT}_{1 \mathrm{~A}}$ receptor sensitivity in major depression: A neuroendocrine study with buspirone. Br J Psychiatry 164:372-379

Crow TJ, Cross AJ, Cooper SJ, Deakin JFW, Ferrier IN, Johnson JA, Joseph $\mathrm{MH}$, Owen F, Poulter M, Lofthouse R, Corsellis JAN, Chambers DR, Blessed G, Perry EK, Perry RH, Tomlinson BE (1984): Neurotransmitter receptors and monoamine metabolites in the brains of patients with Alzheimer-type dementia and depression, and suicides. Neuropharmacology 23:1561-1569
Deakin JF, Pennell L, Upadhyaya AJ, Lofthouse R (1990): A neuroendocrine study of $5 \mathrm{HT}$ function in depression: Evidence for biological mechanisms of endogenous and psychosocial causation. Psychopharmacol Ser (Berl) 101: 85-92

Edman G, Åsberg M, Levander S, Schalling D (1986): Skin conductance habituation and cerebrospinal fluid 5-hydroxyindoleacetic acid in suicidal patients. Arch Gen Psychiatry 43:586-592

Endicott J, Spitzer RL, Fleiss JL, Cohen J (1976): The global assessment scale. Arch Gen Psychiatry 33:766-771

Fuller RW, Snoddy HD, Robertson DW (1988): Mechanisms of effects of d-fenfluramine on brain serotonin metabolism in rats: Uptake inhibition versus release. Pharmacol Biochem Behav 30:715-721

Gibbons RD, Davis JM (1986): Consistent evidence for a biological subtype of depression characterized by low CSF monoamine levels. Acta Psychiatr Scand 74:8-12

Golden RN, Ekstrom D, Brown TM, Ruegg R, Evans DL, Haggerty JJ, Jr, Garbutt JC, Pedersen CA, Mason GA, Browne J, Carson SW (1992): Neuroendocrine effects of intravenous clomipramine in depressed patients and healthy subjects. Am J Psychiatry 149:1168-1175

Gross-Isseroff R, Israeli M, Biegon A (1989): Autoradiographic analysis of tritiated imipramine binding in the human brain post mortem: Effects of suicide. Arch Gen Psychiatry 46:237-241

Hamilton M (1960): A rating scale for depression. J Neurol Neurosurg Psychiatry 23:56-62

Heninger GR, Charney DS, Sternberg DE (1984): Serotonergic function in depression: Prolactin response to intravenous tryptophan in depressed patients and healthy subjects. Arch Gen Psychiatry 41:398-402

Heninger GR, Delgado PL, Charney DS, Price LH, Aghajanian GK (1992): Tryptophan-deficient diet and amino acid drink deplete plasma tryptophan and induce a relapse of depression in susceptible patients. J Chem Neuroanat $5: 347-348$

Invernizzi K, Kmieciak-Kolada K, Samamin R (1992): Is receptor activation involved in the mechanism by which (+)-fenfluramine and (+)-norfenfluramine deplete 5-hydroxytryptamine in the rat brain? $\mathrm{Br} \mathrm{J}$ Pharmacol 75:525-530

Jones JS, Stanley B, Mann JJ, Frances AJ, Guido JR, TräskmanBendz L, Winchel R, Brown RP, Stanley M (1990): CSF 5-HIAA and HVA concentrations in elderly depressed patients who attempted suicide. Am J Psychiatry 147:1225-1227

Kahn RS, Wetzler S, Asnis GM, Papolos D, van Praag HM (1990): Serotonin receptor sensitivity in major depression. Biol Psychiatry 28:358-362

Kaplan RD, Mann JJ (1982): Altered platelet serotonin uptake kinetics in schizophrenia and depression. Life Sci 3:583-588

Kapur S, Mann JJ (1992): Role of the dopaminergic system in depression. Biol Psychiatry 32:1-17

Kasper S, Vieira A, Schmidt R, Richter P (1990): Multiple hormone response to stimulation with $d l$-Fenfluramine in patients with major depression before and after antidepressive treatment. Pharmacopsychiatry 23:76-84 
Kjellman BF, Ljunggren J-G, Beck-Friis J, Wetterberg L (1983): Effect of TRH on TSH and prolactin levels in affective disorders. Psychiatry Res 14:353-363

Korpi ER, Kleinman J, Goodman SI, Phillips I, DeLisi LE, Linnoila M, Wyatt RJ (1986): Serotonin and 5-hydroxyindoleacetic acid in brains of suicide victims: Comparison in chronic schizophrenic patients with suicide as cause of death. Arch Gen Psychiatry 43:594-600

Koyama T, Lowry MT, Meltzer HY (1987): 5-Hydroxytryptophan-induced cortisol response and CSF 5-HIAA in depressed patients. Am J Psychiatry 144:334-337

Krebs HA, Cheng LK, Wright GJ (1984): Determination of fenfluramine and norfenfluramine in plasma using a nitrogen-sensitive detector. J Chromatogr Biomed Appl 310:412-417

Langer SZ, Galzin AM, Poirer MF, Loo H, Sechter D, Zarifian $E$ (1987): Association of $\left[{ }^{3} \mathrm{H}\right]$ imipramine and $\left[{ }^{3} \mathrm{H}\right]$ paroxetine with the 5-HT transporter in brain and platelets: Relevance to studies in depression. J Recept Res 7:499-521

Lerer B, Ran A, Blacker M, Silver H, Weller MPI, Drummer D, Ebstein B, Calev A (1988): Neuroendocrine responses in chronic schizophrenia evidence for serotonergic dysfunction. Schizophr Res 1:405-410

Lesch KP (1991): The ipsapirone/5- $\mathrm{HT}_{1 \mathrm{~A}}$ receptor challenge in anxiety disorders and depression. Int Congr Ser 968: 905-908

Lichtenberg P, Shapira B, Gillon D, Kindler S, Cooper TB, Newman ME, Lerer B (1992): Hormone responses to fenfluramine and placebo challenge in endogenous depression. Psychiatry Res 43:137-146

Lloyd KG, Farley IJ, Deck JHN, Hornykiewicz O (1974): Serotonin and 5-hydroxyindoleacetic acid in discrete areas of the brainstem of suicide victims and control patients. Adv Biochem Psychopharmacol 11:387-397

Lopez-Ibor JJ, Saiz-Ruiz R, Perez de los Cobos JC (1985): Biological correlations of suicide and aggressivity in major depressions (with melancholia): 5-Hydroxyindoleacetic acid and cortisol in cerebral spinal fluid, dexamethasone suppression test and therapeutic response to 5-hydroxytryptophan. Neuropsychobiology 14:67-74

Lopez-Ibor JJ, Jr, Saiz-Ruiz J, Iglesias LM (1988): The fenfluramine challenge test in the affective spectrum: A possible marker of endogeneity and severity. Pharmacopsychiatry 21:9-14

Lopez-Ibor JJ, Jr, Lana F, Saiz Ruiz J (1990) Impulsive suicidal behavior and serotonin. Actas Luso Esp Neurol Psiquiatr Cienc Afines 18:316-325

Maes M, Jacobs MP, Suy E, Minner B, Raus J (1989): Cortisol, $\mathrm{ACTH}$, prolactin and beta-endorphin responses to fenfluramine administration in major-depressed patients. Neuropsychobiology 21:192-196

Malone KM, Mann JJ (1993): Serotonin and major depression. In Mann JJ, Kupfer DJ (eds), Biology of Depressive Disorders, vol. 3, part A: A System Perspective. New York, Plenum Press, pp 29-49

Mann JJ, Stanley M (eds) (1986): Psychobiology of Suicidal Behavior. New York, New York Academy of Sciences

Mann JJ, Stanley M, McBride PA, McEwen BS (1986): Increased serotonin 2 and $\beta$-adrenergic receptor binding in the frontal cortices of suicide victims. Arch Gen Psychiatry 43:954-959
Mann JJ, McBride PA, Brown RP, Linnoila M, Leon AC, DeMeo MD, Mieczkowski TA, Myers JE, Stanley M (1992): Relationship between central and peripheral serotonin indexes in depressed and suicidal psychiatric inpatients. Arch Gen Psychiatry 49(6):442-446

McBride PA, Tierney H, DeMeo M, Chen J-S, Mann JJ (1990): Effects of age and gender on CNS serotonergic responsivity in normal adults. Biol Psychiatry 27:1143-1155

Meltzer HY, Maes M (1994): Effects of buspirone on plasma prolactin and cortisol levels in major depressed and normal subjects. Biol Psychiatry 35:316-323

Meltzer HY, Arora RC, Baber R, Tricou B-J (1981): Serotonin uptake in blood platelets of psychiatric patients. Arch Gen Psychiatry 38:1322-1326

Meltzer HY, Perline R, Tricou BJ, Lowy M, Robertson A (1984): Effect of 5-hydroxytryptophan on serum cortisol levels in major affective disorders, II: Relation to suicide, psychosis and depressive symptoms. Arch Gen Psychiatry 41:379-387

Meyendorff E, Jain A, Träskman-Bendz L, Stanley B, Stanley M (1986): The effects of fenfluramine on suicidal behavior. Psychopharmacol Bull 22:155-159

Mitchell P, Smythe G (1990): Hormonal responses to fenfluramine in depressed and control subjects. J Affective Disord 19:43-51

Mitchell P, Smythe G, Parker G, Wilhelm K., Brodaty H, Boyce P, Hickie I (1990): Growth hormone and other hormonal responses to clonidine in melancholic and nonmelancholic depressed subjects and controls. Psychiatry Res 37:179-193

Moses SG, Robins E (1975): Regional distribution of norepinephrine and dopamine in brains of depressive suicides and alcoholic suicides. Psychopharmacol Commun 1: 327-337

Muhlbauer HD, Muller-Oerlinghausen B (1985): Fenfluramine stimulation of serum cortisol in patients with major affective disorders and healthy controls: Further evidence for a central serotonergic action of lithium in man. J Neural Transm 61:81-94

Nordin C (1988): Relationships between clinical symptoms and monoamine metabolite concentrations in biochemically defined subgroups of depressed patients. Acta Psychiatr Scand 78:720-729

O'Keane V, Dinan TG (1991): Prolactin and cortisol responses to $d$-fenfluramine in major depression: Evidence for diminished responsivity of central serotonergic function. Am J Psychiatry 148:1009-1015

O'Keane V, O'Hanlon M, Webb M, Dinan T (1991): D-fenfluramine/prolactin response throughout the menstrual cycle: evidence for an oestrogen-induced alteration. Clinical Endocrinology 34:289-292

O'Keane V, McLoughlin D, Dinan TG (1992a): D-fenfluramine-induced prolactin and cortisol release in major depression: Response to treatment. J Affective Discord 26: 143-150

O'Keane V, Moloney E, O'Neill H, O'Connor A, Smith C, Dinan TG (1992b): Blunted prolactin responses to d-fenfluramine in sociopathy: Evidence for subsensitivity of central serotonergic function. Br J Psychiatry 160:643-646

Palaniappan V, Ramachandran V, Somasundaram O (1983): Suicidal ideation and biogenic amines in depression. Indian J Psychiatry 25(4):286-292 
Pare CMB, Yeung DPH, Price K, Stacey RS (1969): 5-Hydroxytryptamine, noradrenaline, and dopamine in brainstem, hypothalamus, and caudate nucleus of controls and of patients committing suicide by coal-gas poisoning. Lancet 2:133-135

Paul SM, Rehavi M, Skolnick P, et al. (1984): High affinity binding of antidepressants to a biogenic amine transport site in human brain and platelet: Studies in depression. In Post RM, Bellinger CJ (eds), Neurobiology of Mood Disorders. Baltimore, Williams and Wilkins, pp 846-853

Peabody CA, Faull KF, King RJ, Whiteford HA, Barchas JD, Berger PA (1987): CSF amine metabolites and depression. Psychiatry Res 21:1-7

Peroutka SJ, Snyder SH (1980): Regulation of serotonin $\left(5 \mathrm{HT}_{2}\right)$ receptors labeled with ${ }^{3} \mathrm{H}$-spiroperidol by chronic treatment with the antidepressant amitryptiline. J Pharmacol Exp Ther 215:582-587

Price LH, Charney DS, Delgado PL, Heninger GR (1991): Serotonin function and depression: Neuroendocrine and mood responses to intravenous L-tryptophan in depressed patients and healthy comparison subjects. Am J Psychiatry 148:1518-1525

Roy A, Ågren H, Pickar D, Linnoila M, Doran A, Cutler N, Paul SM (1986): Reduced CSF concentrations of homovanillic acid and homovanillic acid to 5-hydroxyindoleacetic acid ratios in depressed patients: Relationship to suicidal behavior and dexamethasone nonsuppression. Am J Psychiatry 143:1539-1545

Roy-Byrne P, Post RM, Rubinow DR, Linnoila M, Savard R, Davis D (1983): CSF 5HIAA and personal and family history of suicide in affectively ill patients: A negative study. Psychiatry Res 10:263-274

Secunda SK, Cross CK, Koslow S, Katz MM, Kocsis J, Maas JW, Landis H (1986): Biochemistry and suicidal behavior in depressed patients. Biol Psychiatry 21:756-767

Shaw DM, Camps FE, Eccleston EG (1967): 5-Hydroxytryptamine in the hind-brain of depressive suicides. Br J Psychiatry 113:1407-1411

Shopsin B, Gershon S, Goldstein M, Friedman E, Wilk S (1975): Use of synthesis inhibitors in defining a role for biogenic amines during imipramine treatment in depressed patients. Psychopharmacol Commun 1(2): 239-249

Shopsin B, Friedman E, Gershon S (1976): Parachlorophenylalanine reversal of tranylcypromine effects in depressed patients. Arch Gen Psychiatry 33:811-819

Siever LJ, Murphy DL, Slater S, de la Vega E, Lipper S (1984): Plasma prolactin changes following fenfluramine in depressed patients compared to controls: An evaluation of central serotonergic responsivity in depression. Life Sci 34:1029-1039

Spitzer RL, Endicott J (1978): Schedule for Affective Disorders and Schizophrenia (SADS). New York, New York State Psychiatric Institute.

Stanley M, Mann JJ (1983): Increased serotonin-2 binding sites in frontal cortex of suicide victims. Lancet 1:214-216

Stanley M, Virgilio J, Gershon S (1982): Tritiated imipramine binding sites are decreased in the frontal cortex of suicides. Science 216:1337-1339

Stanley M, Mann JJ, Gershon S (1983): Alterations in pre- and postsynaptic serotonergic neurons in suicide victims. Psychopharmacol Bull 19:684-687

Targum SD (1990): Differential responses to anxiogenic challenge studies in patients with major depressive disorder and panic disorder. Biol Psychiatry 28:21-34

Träskman L, Åsberg M, Bertilsson L, Sjöstrand L (1981): Monoamine metabolites in CSF and suicidal behavior. Arch Gen Psychiatry 38:631-636

van Praag HM (1982): Depression, suicide and the metabolism of serotonin in the brain. J Affective Disord 4:275-290

Vestergaard P, Sorensen T, Hoppe E, Rafaelsen OJ, Yates CM, Nicolaou N (1978): Biogenic amine metabolites in cerebrospinal fluid of patients with affective disorders. Acta Psychiatr Scand 58:88-96

Weizman A, Mark M, Gil-Ad I, Tyano S, Laron Z (1988): Plasma cortisol, prolactin, growth hormone, and immunoreactive beta-endorphin response to fenfluramine challenge in depressed patients. Clin Neuropharamacol $11: 250-256$

Westenberg HG, Verhoeven WM (1988): CSF monoamine metabolites in patients and controls: Support for a bimodal distribution in major affective disorders. Acta Psychiatr Scand 78:541-549 